\title{
Size-Dependent Effects of Suspended Graphene Oxide Nanoparticles on the Cellular Fate of Mouse Neural Stem Cells
}

This article was published in the following Dove Press journal: International Journal of Nanomedicine

\author{
Lijuan $\operatorname{Lin}^{1,2, *}$ \\ Xizhen Zhuang ${ }^{1,2, *}$ \\ Ruiqi Huang' \\ Simin Song' \\ Zhaojie Wang ${ }^{1,2}$ \\ Shilong Wang (D) ${ }^{3}$ \\ Liming Cheng ${ }^{1,2}$ \\ Rongrong Zhu ${ }^{\mathrm{l}, 2}$
}

'Division of Spine, Department of Orthopedics, Tongji Hospital Affiliated to Tongii University School of Medicine, School of Life Science and Technology, Tongji University, Shanghai, People's Republic of China; ${ }^{2}$ Key Laboratory of Spine and Spinal Cord Injury Repair and Regeneration (Tongji University), Ministry of Education, Shanghai, People's Republic of China; ${ }^{3}$ Research Center for Translational Medicine at East Hospital, School of Life Science and Technology, Tongji University, Shanghai, People's Republic of China

*These authors contributed equally to this work

\begin{abstract}
Purpose: In this study, we aim to explore the effects of graphene oxide (GO), a derivative of graphene, nanoparticles of four different sizes on the cellular fate of mouse neural stem cells (mNSCs).
\end{abstract}

Methods: GO NPs were characterized with transmission electron microscopy (TEM), scanning electron micrography (SEM), atomic force microscopy (AFM) and Raman Spectra analysis. The cytotoxic effects of the GO NPs of different sizes on the mNSCs were determined using CCK-8 assay, Annexin V-APC/ 7-AAD staining and EdU staining assays. We investigated the biological and the mechanisms of GO NPs on cells using immunofluorescence analysis and quantitative real-time PCR (qPCR).

Results: The average hydrodynamic sizes of the GO NPs were $417 \mathrm{~nm}, 663 \mathrm{~nm}, 1047 \mathrm{~nm}$, and $4651 \mathrm{~nm}$, with a thickness of approximately $22.5 \mathrm{~nm}, 17.7 \mathrm{~nm}, 22.4 \mathrm{~nm}$, and $13.4 \mathrm{~nm}$, respectively. GO NPs of all sizes showed low cytotoxicity at a concentration of $20 \mu \mathrm{g} / \mathrm{mL}$ on the mNSCs. Immunostaining demonstrated that treatment with GO NPs, especially the $663 \mathrm{~nm}$ ones, enhanced the self-renewal ability of mNSCs in the absence of EGF and bFGF. Under differentiation medium conditions that are free of mitogenic factors, all the GO NPs, particularly the $4651 \mathrm{~nm}$ ones, increased the expression level of Tuj1 and GFAP. With regards to the migration ability, we found that $417 \mathrm{~nm}$ GO-NP-treated mNSCs migrated over a longer distance than the control group obviously. In addition, higher expression of Rap1, Vinculin and Paxillin was observed in the GO NP-treated groups compared to the control group. mRNA-Sequence analysis and Western blotting results suggested that the $4651 \mathrm{~nm}$ GO NPs triggered positive neuronal differentiation through phosphorylation of ERK1/2 by the downregulating of TRPC2. Conclusion: GO NPs play an important role in the applications of inducing self-renewal and differentiation of $\mathrm{mNSC}$, and are promising in the future for further studies.

Keywords: graphene oxide, neural stem cells, size-dependent, self-renewal, differentiation

\section{Introduction}

NSCs are pluripotent and self-renewing cells found in the central nervous system, ${ }^{1,2}$ and they can differentiate into neurons, oligodendrocytes and astrocytes under specific culture conditions. ${ }^{3-5}$ Due to these characteristics, they have become one of the most promising candidates for neural regeneration, as well as brain repair. ${ }^{6-8}$ However, it is challenging to control the eventual fate of NSCs, which restricts the application of NSCs in tissue engineering and regenerative medicine.

One of the traditional methods to control the growth and differentiation of NSCs is to culture them in a medium containing both chemical inducers and growth
Cheng

Division of Spine, Department of Orthopedics, Tongji Hospital Affiliated to Tongji University School of Medicine, School of Life Science and Technology, Tongji University, Shanghai 200065,

People's Republic of China

Tel +86 2l 66III 330

Email rrzhu@tongji.edu.cn;

limingcheng@tongji.edu.cn
International Journal of Nanomedicine 2020:15 |42|-|435

|42|

DovePress $f$ in $\boldsymbol{v}$

http://doi.org/10.2147/IN.S225722 
factors. Mitogen signals such as basic fibroblast growth factor (bFGF) and epidermal growth factor (EGF) are widely considered to play a crucial role in the proliferation and differentiation of NSCs in vitro, as well as in maintaining their self-renewal ability of NSCs. ${ }^{9}$

Nanotechnology involves the development of nanomaterials in sizes ranging from 1 to $100 \mathrm{~nm} .{ }^{10}$ At such a small scale, the physical, chemical, and biological properties of materials are often quite different, which has brought unprecedented possibilities for its usage in the field of drug delivery, imaging, diagnostics, and other medical applications, especially stem cell research. ${ }^{11-13}$

Over the past few decades, researches on graphene have been increasing rapidly for applications in fields of nanomaterials and nanotechnology, especially in tissue engineering and regenerative medicine. ${ }^{14}$ Graphene is a two-dimensional nanoparticle comprising of a single layer with six atoms arranged in a honeycomb lattice in $\mathrm{sp}^{2}$ hybridization. ${ }^{15}$ Of all its derivatives, graphene oxide, is notably favored for stem cell research because of its excellent biocompatibility, as well as outstanding electrical, thermal, mechanical and chemical properties. ${ }^{16}$ In fact, great values of graphene oxide in many promising applications of GO NPs have been reported recently, ${ }^{17,18}$ including biosensing, ${ }^{19,20}$ cell imaging, ${ }^{21}$ drug delivery, ${ }^{21-24}$ gene delivery, ${ }^{25}$ cancer therapy ${ }^{22,23}$ and tissue engineering. ${ }^{24}$ Moreover, stem cells treated with GO were found to show enhanced neural differentiation. ${ }^{26-28}$ However, only a few reports have research focused on exploring the effects of the sizes of the GO NPs on the cellular functions of NSCs.

In this study, we explored the size-dependent effects of GO NPs on the self-renewal and differentiation of mNSCs. GO NPs with mean sizes of $417 \mathrm{~nm}, 663 \mathrm{~nm}, 1047 \mathrm{~nm}$ and $4651 \mathrm{~nm}$ were prepared and used for treating the cells. Then we evaluated the cytotoxicity of these NPs, as well as their effect on the cell cycle, cell proliferation, pluripotency, potential for differentiating into specific lineages and migration of mNSCs. Furthermore, we evaluated the role of GO NPs play in maintaining the self-renewal of the mNSCs in place of EGF and bFGF. Our research demonstrated that the particle size of GO had an effect on controlling the fate and cellular functions of mNSCs.

\section{Materials and Methods}

\section{Materials}

Graphene oxide nanoparticles of different sizes were purchased from Aladdin Co. and Nanjing JiCang Nano Technology Co., Ltd.

\section{Characterization of Nanoparticles}

A transmission electron microscope (TEM, JEOL-1230, Japan) was used to observe the morphology of the GO NPs. The samples were dispersed in double-distilled water and several drops of each suspension were placed on the carbon-coated copper TEM grid. The diameter and zeta potential of different particles were measured using the Malvern zeta sizer nano-zs90 (Malvern, UK). The thickness and roughness of GO NPs were examined by atomic force microscopy (AFM). The structure and mechanical properties were analyzed using by Raman spectrometry by exciting with a $514 \mathrm{~nm}$ argon laser (Renishaw, UK).

\section{Cell Culture}

Mouse NSCs were isolated from the forebrain of $\mathrm{C} 57$ mice at E13.5. ${ }^{29}$ The use of cells was approved by the Ethical Committee of Tongji University of Medicine. Mice, from which we isolated cells, were approved by the Institutional Animal Care Committee of Tongji University. We have complied with all relevant ethical regulations. Cells were cultured as neurospheres in Dulbecco's modified eagle's medium/nutrient mixture F-12 (DMEM/F12) medium (Gibco), supplemented with 2\% B-27 (Gibco), $1 \mathrm{mM}$ L-glutamine (Gibco), 1\% nonessential amino acids (Gibco), basic fibroblast growth factor (bFGF) (20 ng/mL, Peprotech), and epidermal growth factor (EGF) (20 ng/mL, Peprotech). One half of the culture medium was replaced with fresh medium every 2 days. The mNSCs were cultured in a humidified incubator with $5 \% \mathrm{CO} 2$ at $37^{\circ} \mathrm{C}$.

\section{Cytotoxicity Assay}

The cytotoxicity of the NPs was indicated by the relative cell viability compared with the control group and was examined using a CCK-8 cell proliferation kit (KeyGen Biotech, China). The cell suspension $(100 \mu \mathrm{L})$ were cultured in 96-well plates with a density is $1 \times 10^{4}$ cells in per well. Then, fresh culture medium containing GO NPs of different sizes at the concentration of 5, 10,20, 50 , and $100 \mu \mathrm{g} / \mathrm{mL}$ was added to the wells, and cells treated only with medium were used as the control. CCK-8 reagent $(10 \mu \mathrm{L})$ was added to each well, and the plates were incubated for another $1-4 \mathrm{~h}$ at $37^{\circ} \mathrm{C}$ in the darkness. The absorbance was measured at a wavelength of $450 \mathrm{~nm}$ using a microplate reader (SpectraMax M5, Molecular Devices).

\section{Cell Apoptosis Assay}

mNSCs were seeded into six-well plates. GO NPs at a fixed concentration of $20 \mu \mathrm{g} / \mathrm{mL}$ were added to each 
well and incubated for $24 \mathrm{~h}$. Subsequently, cells from different treatment groups were harvested and rinsed twice with PBS. They were labeled with Annexin V-FITC/PI using an Apoptosis Detection Kit (KeyGen Biotech, China) and examined using a flow cytometer (Becton Dickinson, USA). The Flowjo software was used to analyze the results. ${ }^{30}$

\section{Cell Cycle Assay}

We examined the effect of the GO NPs on the cell cycle of mNSCs using the cell cycle detection kit (KeyGen Biotech, China). mNSCs were seeded into six-well plates (at a density of $1 \times 10^{5}$ cells per well). Following that, $20 \mu \mathrm{g} /$ $\mathrm{mL}$ of GO NPs were added to the wells and incubated for 24 $\mathrm{h}$. The cells were then harvested and fixed in $70 \%$ ethanol (ice-cold) at $4^{\circ} \mathrm{C}$ overnight. Subsequently, the cells were resuspended in PBS ( $\mathrm{pH} 7.4$ ), incubated with RNase A (40 $\mu \mathrm{g} / \mathrm{mL})$ and PI $(10 \mu \mathrm{g} / \mathrm{mL})$, and then kept in the darkness. Finally, flow cytometry (Becton Dickinson, USA) was performed and the results were Flowjo software.

\section{EdU Cell Proliferation Assay}

The effect of GO NPs on the proliferation of mNSCs was tested by using the Click-iT Edu Kit (KeyGen Biotech, China) with the Alexa Fluor488 dye. The mNSCs were seeded on poly-L-ornithine (PLO)-coating six-well plates at a concentration of $1.0 \times 10^{5}$ cells per well and cultured till attachment. After an overnight incubation, the culture medium was replaced with the medium containing $20 \mu \mathrm{g} / \mathrm{mL}$ of GO NPs. After a $24 \mathrm{~h}$ incubation period, the samples were treated using the kit according to the manufacturer's instructions. The proliferation rate indicated by the fluorescence intensity was observed using a fluorescence microscope.

\section{Induction of Spontaneous Differentiation of $\mathrm{mNSCs}$}

To induce spontaneous differentiation of $\mathrm{mNSCs}$, neurospheres were seeded onto PLO-coating six-well plates, which are known to support the adhesion of NSCs. GO NPs at a concentration of $20 \mu \mathrm{g} / \mathrm{mL}$ were added, and the cells were incubated in differentiation medium free of mitogenic factors for $24 \mathrm{~h}$. The cells were subsequently harvested for immunofluorescence and subjected to qPCR.

\section{Cell Migration}

The mNSCs were passaged every 4 days and on the 3 rd day after passage, neurospheres were seeded into PLO-coated six-well plates and cultured till attachment. GO NPs at a concentration of $20 \mu \mathrm{g} / \mathrm{mL}$ were then added and incubated for $24 \mathrm{~h}$. The morphology and migration distances of the samples were observed under a bright field of photon microscope (Nikon ECLIPSE Ti) and confocal microscope (LSM 700, Carl Zeiss, Jena, Germany).

\section{Immunofluorescence}

mNSCs were fixed with $4 \%(\mathrm{w} / \mathrm{v})$ paraformaldehyde at $37^{\circ} \mathrm{C}$ for $15 \mathrm{~min}$ and washed three times with PBS. The samples were permeabilized with $0.3 \%(\mathrm{v} / \mathrm{v})$ Triton $\mathrm{X}-100$ for $10 \mathrm{~min}$, and then washed and blocked with $5 \%(\mathrm{v} / \mathrm{v})$ goat serum for 1 $\mathrm{h}$. The samples were incubated at $4^{\circ} \mathrm{C}$ overnight with primary antibodies as follows: mouse monoclonal anti-Nestin (1:200, Abcam), mouse monoclonal anti-NeuN (1:200, Abcam, conjugated with AlexaFluor 488) and mouse monoclonal antiGFAP (1:200, Abcam, conjugated with Cy3). After gently rinsing with PBS, the samples were incubated with secondary antibodies [AlexaFluor 488-conjugated goat anti-mouse IgG (Invitrogen) for $1 \mathrm{~h}$. The nuclei were stained with 4',6-diamidino-2-phenylindole (DAPI) and the fluorescence images were taken using a confocal microscope (LSM 700, Carl Zeiss, Jena, Germany).

\section{Western Blotting}

After treatment with GO NPs treatments, the cells were collected and washed with PBS, and the total proteins were extracted. The membranes were blocked in $5 \%(\mathrm{w} / \mathrm{v})$ bovine serum albumin (BSA) in TBST was incubated overnight with primary antibodies ( $\beta$-actin, ERK1/2, and p-ERK1/2) overnight at $4^{\circ} \mathrm{C}$. After washing with TBST several times, the membranes were incubated with second antibodies for 60 mins at room temperature. A chemiluminescence detection system (Santa Cruz Biotechnology, Santa Cruz, CA, USA) was used to observe bands. The primary antibodies used in this study included $\beta$-actin(ab8227, Abcam), ERK1/2 (ab184699, Abcam), and pERK1/2(ab32538, Abcam).

\section{Quantitative Real-Time PCR}

The total RNA was isolated from the mNSCs using the Trizol $^{\circledR}$ reagent (Invitrogen). The concentrations and quality of RNA were measured using an ND-1000 spectrophotometer (Nanodrop) for further experiments. cDNA was synthesized with a Primer Script Reverse Transcriptase Kit (Takara) according to the manufacturer's instructions. qPCR was performed using SYBR Premix Ex Taq ${ }^{\text {TM }}$ (Takara) on a 7500 Real-Time PCR System. GAPDH was used as the 
internal reference. Supplementary Figure S1 shows all the primer sequences.

\section{Statistical Analysis}

All results were shown as means \pm standard deviation (SD). Statistical analysis was performed using the Statistical Product and Service Solutions software. One-way analysis of variance was taken for each analysis. Values with $* \mathrm{P}<0.05, * * \mathrm{P}<0.01$, $* * * \mathrm{P}<0.001$ were considered significant.

\section{Results}

\section{Characterization of Graphene Oxide Nanoparticles}

We observed the morphology and surface topography of the GO NPs using TEM and SEM. The images showed the stacked multi-layer structure (Figure 1A), the irregular edges (Figure 1A) and the wrinkle surface (Figure 1B) of the GO NPs. The average hydrodynamic sizes of the GO NPs were $417 \mathrm{~nm}, 663 \mathrm{~nm}, 1047 \mathrm{~nm}$, and $4651 \mathrm{~nm}$ (Figure 1C), which changed to $466 \mathrm{~nm}, 680 \mathrm{~nm}, 1109 \mathrm{~nm}$, and $4638 \mathrm{~nm}$, respectively, in the cell culture medium (Figure S2). These results indicated that there were no obvious differences in the size of the GO NPs in water and in cell culture medium. The average zeta potentials of the GO NPs in water were -32.8 $\mathrm{mV}(417 \mathrm{~nm}),-37 \mathrm{mV}(663 \mathrm{~nm}),-36.8 \mathrm{mV}(1047 \mathrm{~nm})$, and $-35 \mathrm{mV}(4651 \mathrm{~nm})$ (Figure 1D). The thicknesses of the GO NPs detected by AFM were approximately $22.5 \mathrm{~nm}, 17.7$ $\mathrm{nm}, 22.4 \mathrm{~nm}$, and $13.4 \mathrm{~nm}$ for NPs of sizes $417 \mathrm{~nm}, 663 \mathrm{~nm}$, $1047 \mathrm{~nm}$, and $4651 \mathrm{~nm}$, respectively (Figure 1E). The thickness of the single-layered GO NPs was between $0.7 \mathrm{~nm}$ and $1.2 \mathrm{~nm}$, indicating that the NPs in used this study consisted of approximately 10 to 20 layers. The structure and the physical properties of the GO NPs were measured using Raman spectroscopy (Figure 1F). The specific G-band was observed at $\sim 1580 \mathrm{~cm}^{-1}$ and the D-band, which represented sp3 carbon defects, was observed at $\sim 1350 \mathrm{~cm}^{-1}$.

\section{Evaluation of Biocompatibility of Graphene Oxide Nanoparticles}

Before investigating the effects of the GO NPs of different sizes on the self-renewal and differentiation of mNSCs, we tested the cell viability of mNSCs cultured with GO NPs at different concentrations for $24 \mathrm{hrs}$. The CCK- 8 assay demonstrated that GO NPs at concentrations from 5 to $20 \mu \mathrm{g} / \mathrm{mL}$ showed less cytotoxicity after the $24 \mathrm{~h}$ period, but when the cells were exposed to higher concentrations, especially $100 \mu \mathrm{g} / \mathrm{mL}$, the cell viability decreased significantly, confirming that the cytotoxicity of the GO NPs increases in a dose-dependent and size-dependent manner (Figure 2A). Besides, the $417 \mathrm{~nm}$ GO NPs seemed to have lower cytotoxicity than the GO NPs of larger sizes. However, we found that the GO NPs causes cell damage at high concentrations and hence, the concentration of GO NPs was set at $20 \mu \mathrm{g} / \mathrm{mL}$ for the following experiments.

Then, we assessed whether these GO NPs could induce apoptosis in the mNSCs using the annexin V/propidium iodide dual staining assay. Flow cytometry analysis demonstrated that the rate of cellular apoptosis and necrosis were not significantly affected at a concentration of 20 $\mu \mathrm{g} / \mathrm{mL}$ for $24 \mathrm{~h}$ (Figure $2 \mathrm{~B}$ and $\mathrm{C}$ ). ${ }^{30}$ These data indicated that the GO NPs we used in this study were biocompatible with the mNSCs when used at doses under $20 \mu \mathrm{g} / \mathrm{mL}$.

Cell cycle assay is an effective way to detect apoptotic cells. Flow cytometric analysis was used to measure the cell cycle progression of mNSCs treated with GO NPs. After being incubated with $20 \mu \mathrm{g} / \mathrm{mL}$ of GO NPs for $24 \mathrm{~h}$, the cell cycle distribution of mNSCs showed no significant change compared to the control group (Figure 3A and B). The results were within the margin of error, showing good biocompatibility of the GO NPs with mNSCs.

Furthermore, the effects of the GO NPs on the proliferation of mNSCs were then evaluated by the EdU proliferation assay at a concentration of $20 \mu \mathrm{g} / \mathrm{mL}$ for $24 \mathrm{~h}$ (Figure 3C). The intensity of green fluorescence of EdU revealed that the proliferation of mNSCs did not change much in the four GO NPs-treated groups at a concentration of $20 \mu \mathrm{g} / \mathrm{mL}$ compared to the control group (Figure 3D), demonstrating good biocompatibility.

\section{GO NPs Enhanced the Self-Renewal of mNSCs in the Absence of EGF and bFGF}

The aforementioned results showed good biocompatibility of the GO NPs with the cultured mNSCs at concentrations less than $20 \mu \mathrm{g} / \mathrm{mL}$. Then, we examined the effects of GO NPs of different sizes on the self-renewal of mNSCs. The cells were cultured in the proliferation medium with GO NPs for $24 \mathrm{~h}$ and the gene expression of Nestin, which is responsible for pluripotency in the NSCs, was examined by immunofluorescence staining. As shown in Figure 4A, there was no significant change in the morphology and the expression of Nestin did not change significantly. In the absence of EGF and bFGF, we observed under a bright field of microscope that the cells in all four groups treated with GO NPs maintained spherical morphology, whereas the groups not treated with EGF and bFGF, 
A
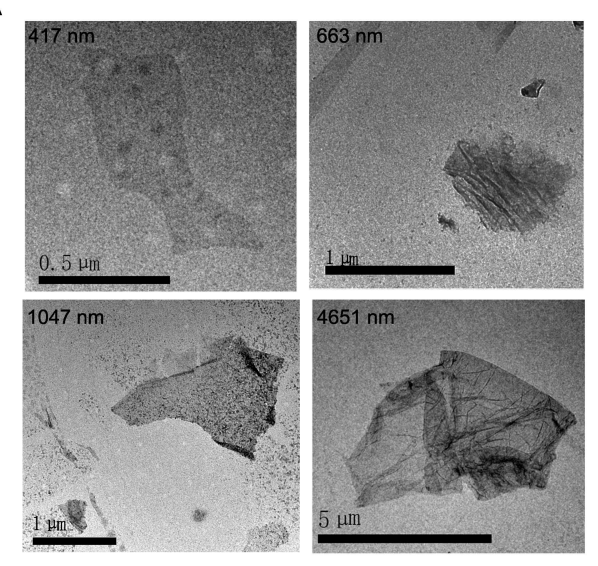

B

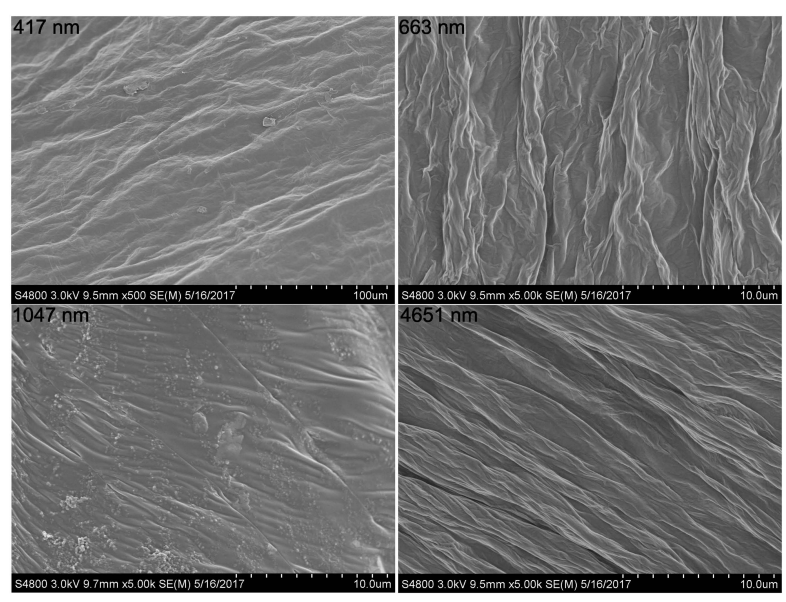

D

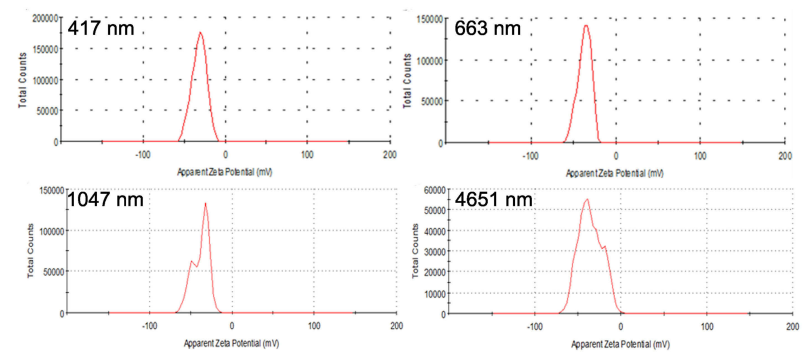

E

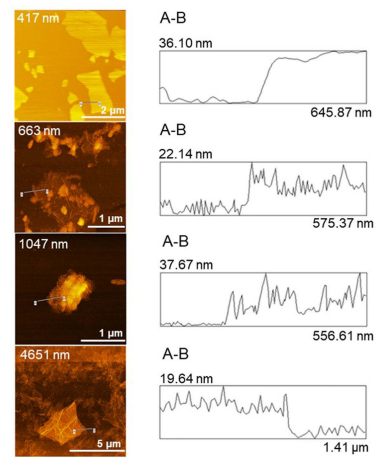

$\mathbf{F}$

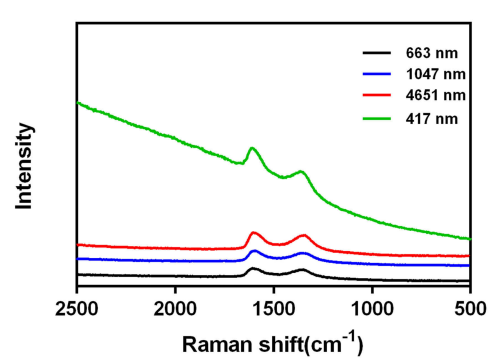

Figure I Characterization of graphene oxide nanoparticles. (A) TEM images of GO NPs; (B) SEM images of GO NPs. Scale Bars: $100 \mu \mathrm{m}$ (for 4 I7 $\mathrm{nm}$ ) I0.0 $\mu \mathrm{m}$ (for $663=\mathrm{nm}, 1047 \mathrm{~nm}$ and $465 \mathrm{Inm}$ ); (C) Size distributions of GO NPs in water; (D) Zeta potentials of GO NPs in water; (E) AFM images of GO NPs; (F) Raman spectra analysis of the GO NPs.

as well as GO NPs showed differentiation (Figure 4C). Immunofluorescence staining was also performed to detect the expression of Nestin in the absence of EGF and bFGF and the green fluorescence signals corresponding to Nestin were stronger in the groups treated with EGF and bFGF and GO NPs than the group without EGF and bFGF (Figure 4B). To further evaluate the effects of the GO NPs on the mNSCs at the mRNA level, total RNA was isolated from the GO NPstreated cells and the expression level of Nestin mRNA was analyzed using qPCR. Treatment with GO NPs of all four sizes, especially the $663 \mathrm{~nm}$ GO NPs, upregulated the mRNA expression of the pluripotency marker Nestin in mNSCs compared with the group without EGF and bFGF, which was consistent with the immunostaining results. (Figure 4D). These results demonstrated that GO NPs enhanced the selfrenewal of mNSCs in the absence of EGF and bFGF.

\section{GO NPs Accelerated the Differentiation of $\mathrm{mNSCs}$}

As we observed that GO NPs enhanced the self-renewal of mNSCs in the absence of EGF and bFGF to some extent, we next evaluated the differentiation potential of the treated cells grown in differentiation medium conditions without mitogenic 
A

24h

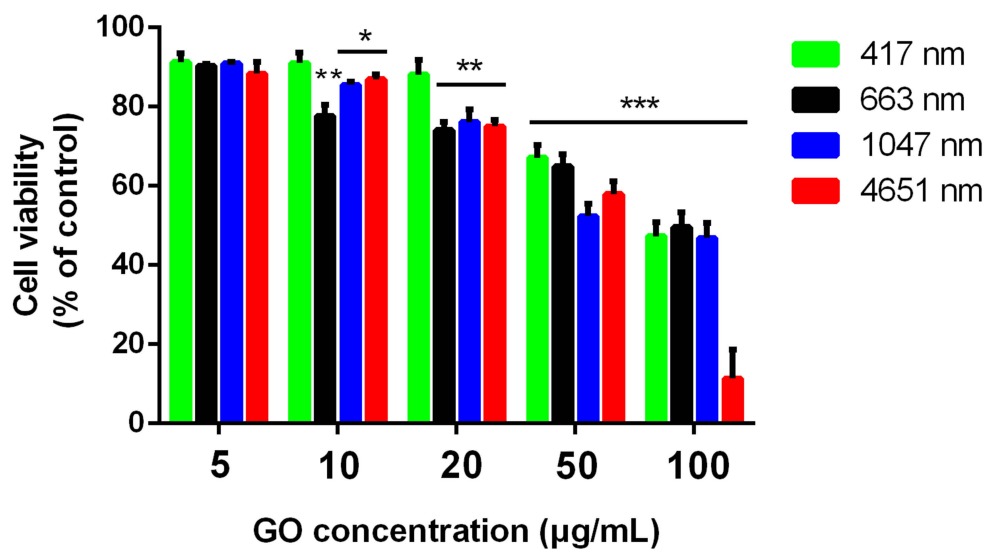

B

\begin{tabular}{|c|c|c|c|}
\hline Control & Control-APC & $\begin{array}{l}\text { Control- } \\
\text { 7-AADD }\end{array}$ & $\begin{array}{l}\text { Control-APC } \\
7-A A D\end{array}$ \\
\hline $\begin{array}{l}417 \mathrm{~nm} \\
\text { GO NPs }\end{array}$ & $\begin{array}{l}663 \mathrm{~nm} \\
\text { GONPs }\end{array}$ & $\begin{array}{l}1047 \mathrm{~nm} \\
\text { GONPs }\end{array}$ & $\begin{array}{l}4651 \mathrm{~nm} \\
\text { GO NPs }\end{array}$ \\
\hline
\end{tabular}
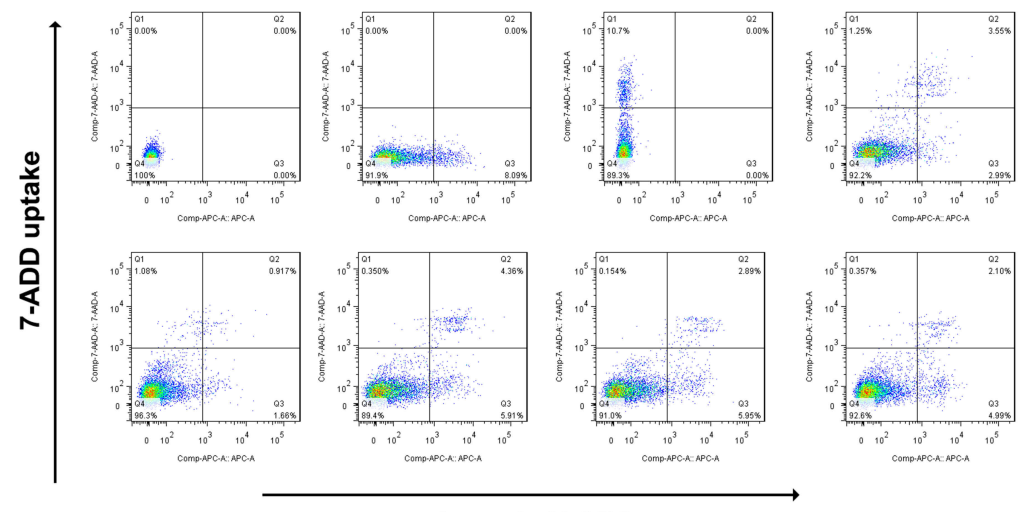

Annexin V-APC

C

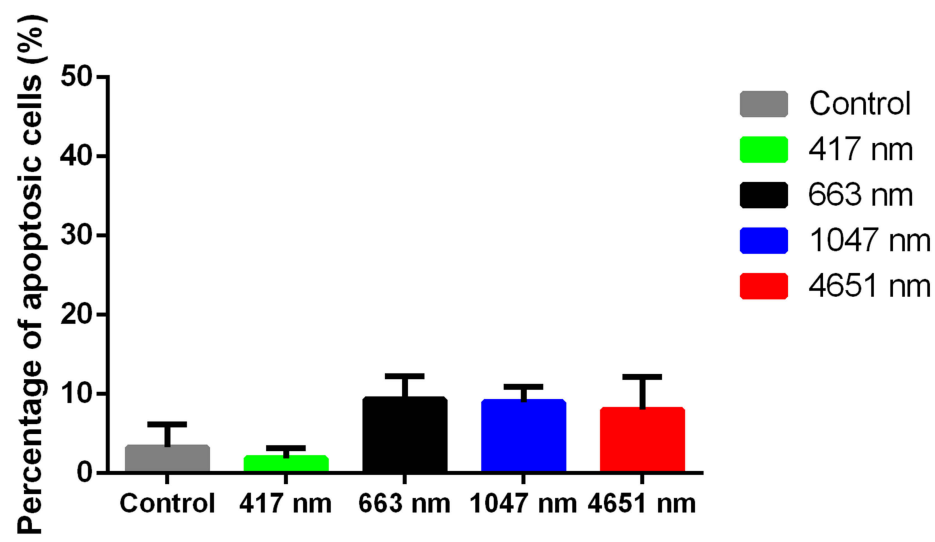

Figure 2 Effect of graphene oxide nanoparticles on the viability and proliferation of mNSCs. (A) CCK-8 assay was performed to evaluate the cell viability of $\mathrm{mNSCs}$ after treatment with $417 \mathrm{~nm}, 663 \mathrm{~nm}, 1047 \mathrm{~nm}$ and $4651 \mathrm{~nm}$ GO NPs at concentrations ranging from 5 to $100 \mu \mathrm{g} / \mathrm{mL}$ for $24 \mathrm{~h}$. Data show the means \pm standard error of the mean of three independent experiments. **** $<0.001$, **p $<0.01$ and $*_{p}<0.05$ compared with the control group. (B) Apoptosis of mNSCs treated with GO NPs of different sizes at a concentration of $20 \mu \mathrm{g} / \mathrm{mL}$ for $24 \mathrm{~h}$. (C) Quantification of cellular apoptosis. Data show the means \pm standard error of the mean. 
A
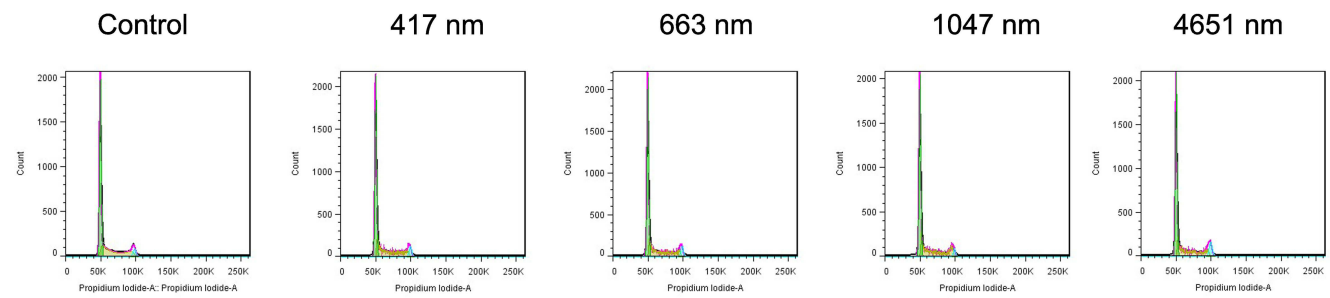

B

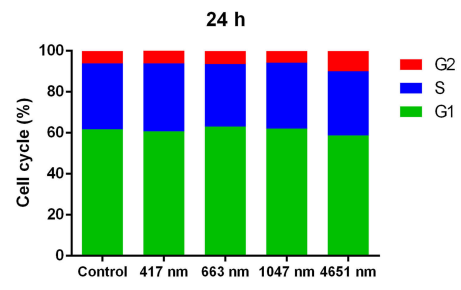

C

Control
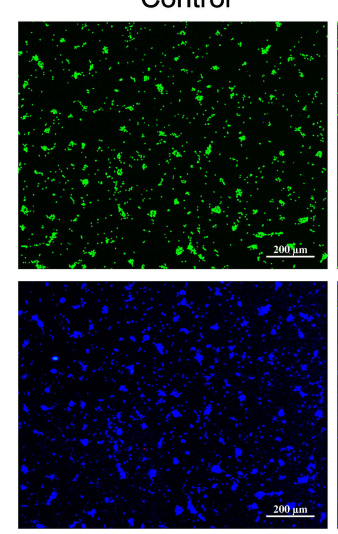

D

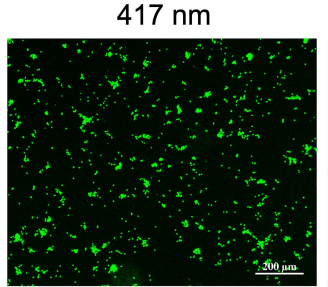

$663 \mathrm{~nm}$
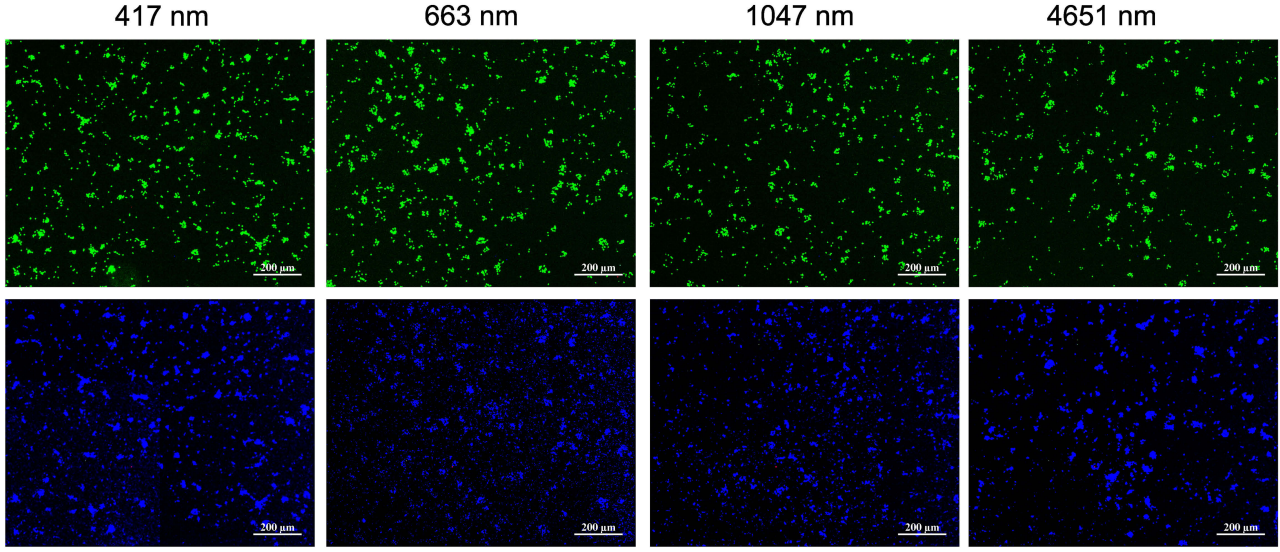

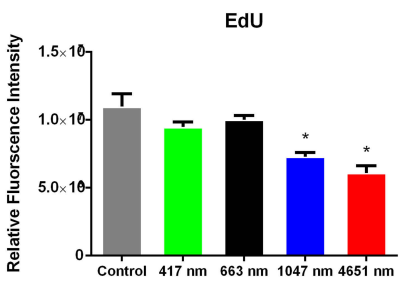

Figure 3 Effects of graphene oxide nanoparticles on the cell cycle and cell proliferation. (A) Effects of exposure to $417 \mathrm{~nm}, 663 \mathrm{~nm}, 1047 \mathrm{~nm}$ and $465 \mathrm{Imm} \mathrm{GO} \mathrm{NPs}$ ( $20 \mu \mathrm{gg} / \mathrm{mL}$ ) for $24 \mathrm{~h}$ on the cell cycle of $\mathrm{mNSCs}$. (B) Percentage distribution of cells in different cell cycle stages. (C) Fluorescence of EdU (green) revealed the proliferation rate of mNSCs treated with $417 \mathrm{~nm}, 663 \mathrm{~nm}, 1047 \mathrm{~nm}$ and $465 \mathrm{Imm}$ GO NPs $(20 \mu \mathrm{g} / \mathrm{mL})$ after $24 \mathrm{~h}$ incubation. Nuclei were stained with DAPI (blue). Scale bars: $200 \mu \mathrm{m}$. (D) Quantification of fluorescence intensity. Data show the means \pm standard error of the mean of three independent experiments. *p $<0.05$ compared with the control group.

factors. NSCs have the capacity to generate three basic neural cell types (neurons, astrocytes, and oligodendrocytes) under spontaneous induced differentiation conditions. The immunofluorescence images showed that neurospheres cultured with $20 \mu \mathrm{g} / \mathrm{mL}$ of GO NPs exhibited higher levels of the expression of neuron specific marker NeuN and astrocyte specific marker GFAP than the control group (Figure 5A), indicating accelerated differentiation of the mNSCs. Moreover, the expression of differentiation-related genes at mRNA level was also analyzed by using qPCR. Tuj1 served as the neuronal marker and GFAP served as the astrocyte marker (Figure 5B). While GO NPs of all four sizes increased the expression levels of Tuj 1 and GFAP, the $4651 \mathrm{~nm}$ GO NPs showed more obvious effects on promoting the differentiation of mNSCs than the other three GO NPs.

\section{GO NPs Improved the Migration of mNSCs}

In the treatment of many neurodegenerative diseases of the central nervous system, even though NSCs can be transplanted exogenously or activated endogenously, these neural stem cells still need to migrate to the area of damage to differentiate into functional neural cells. ${ }^{31,32}$ Hence, we evaluated the effect of GO NPs on the migration ability of mNSCs. We observed the outgrowth and extension of neurites from the GO NPs-treated 
A

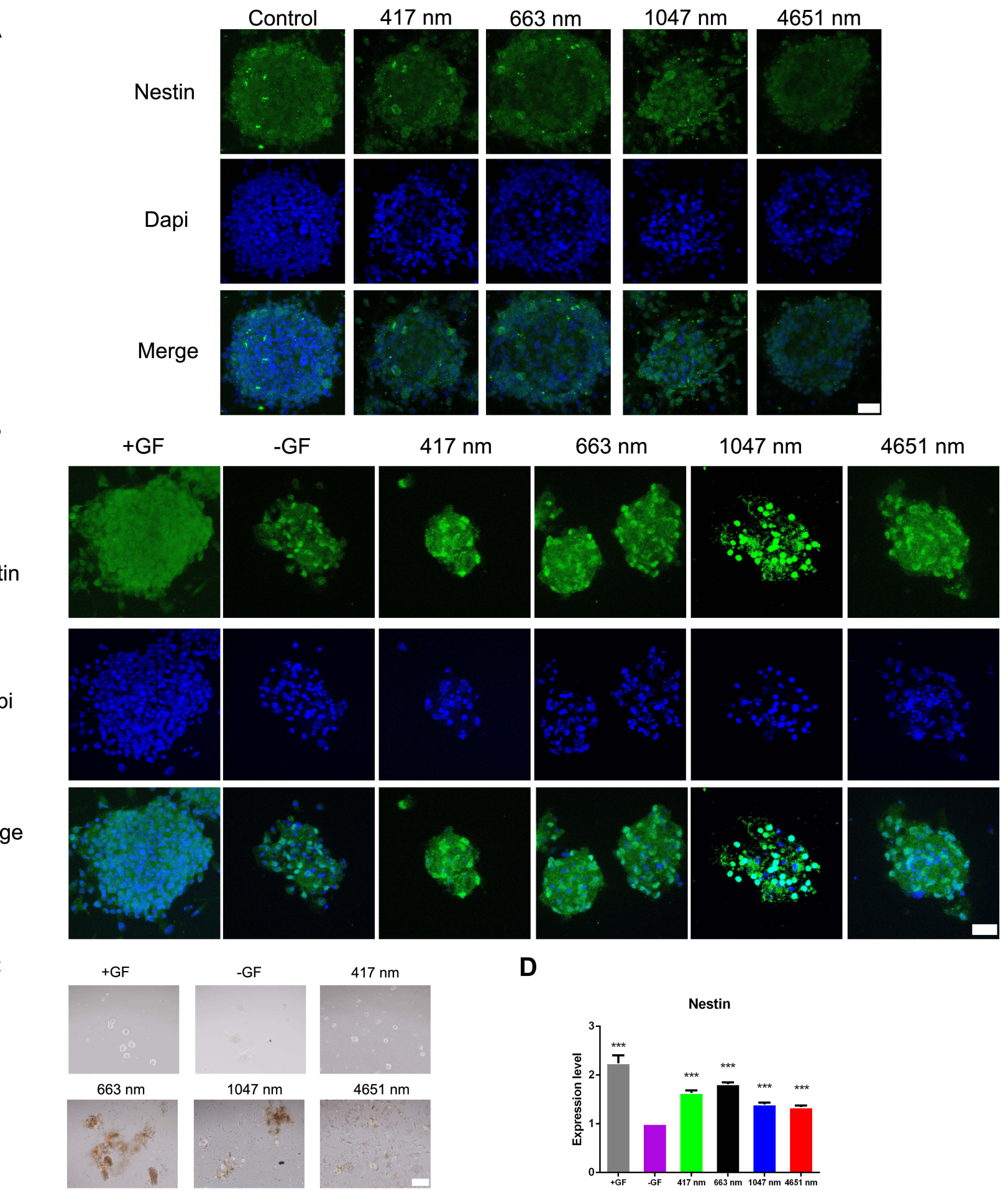

B

Figure 4 Effects of graphene oxide nanoparticles on the self-renewal of mNSCs in the absence of EGF and bFGF. (A) Immunofluorescence images of mNSCs treated with $417 \mathrm{~nm}$, $663 \mathrm{~nm}, 1047 \mathrm{~nm}$ and $465 \mathrm{I} \mathrm{nm} \mathrm{GO} \mathrm{NPs}(20 \mu \mathrm{g} / \mathrm{mL}$ ) for $24 \mathrm{hrs}$. The cells were co-stained with Nestin (green) and nuclei (blue). Scale bars: $20 \mu \mathrm{m}$. (B) Immunofluorescence images of mNSCs treated with $417 \mathrm{~nm}, 663 \mathrm{~nm}, 1047 \mathrm{~nm}$ and $465 \mathrm{I} \mathrm{nm} \mathrm{GO} \mathrm{NPs}(20 \mu \mathrm{g} / \mathrm{mL})$ for $24 \mathrm{hrs}$ in the absence of EGF and bFGF. The cells were co-stained with Nestin (green) and nuclei (blue). Scale bars: $20 \mu \mathrm{m}$. (C) Bright field images of neurospheres treated with $417 \mathrm{~nm}, 663 \mathrm{~nm}, 1047 \mathrm{~nm}$ and $465 \mathrm{Inm}$ GO NPs (20 $\mu \mathrm{g} / \mathrm{mL}$ ) for $24 \mathrm{hrs}$ in the absence of EGF and bFGF. Scale bars: $500 \mu \mathrm{m}$. (D) Relative mRNA expression levels of pluripotency marker gene Nestin, GAPDH was used for internal normalization in the quantitative RT-PCR. Data show the means \pm standard error of the mean of three independent experiments. ${ }^{* * *} \mathrm{p}<0.00 \mathrm{I}$ compared with the cells cultured in the absence of EGF and bFGF.

neurospheres that were attached to the culture plate while the untreated neurospheres maintained their spherical morphology with smooth edges, as seen under the bright field of photon microscope (Figure 6A). Immunostaining results, as shown in Figure $6 \mathrm{~B}$, also indicated that the mNSCs which expressed Nestin, could migrate over a significantly longer distance after 


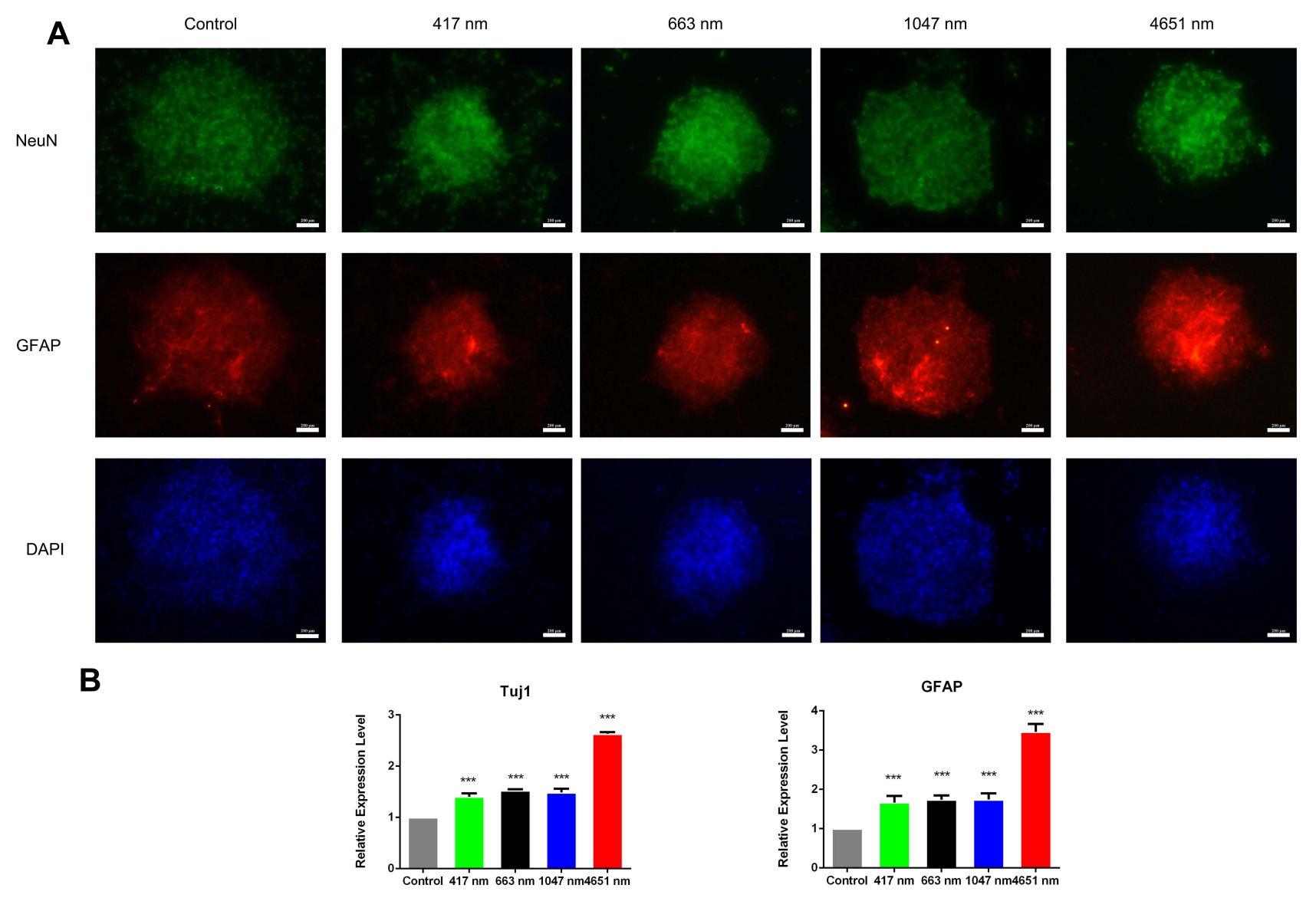

Figure 5 Spontaneous differentiation of neurospheres cultured with graphene oxide nanoparticles. (A) Immunofluorescence images of mNSCs treated with 417 nm, $663 \mathrm{~nm}, 1047 \mathrm{~nm}$ and $465 \mathrm{Im}$ GO NPs $(20 \mu \mathrm{g} / \mathrm{mL}$ ) for $24 \mathrm{hrs}$. The cells were co-stained with NeuN (green), GFAP (red) and nuclei (blue). Scale bars: $200 \mu \mathrm{m}$. (B) Relative mRNA expression levels of the neuron marker gene Tujl and astrocyte marker GFAP were measured. GAPDH was used for internal normalization in the quantitative RTPCR. Data show the means \pm standard error of the mean of three independent experiments. ${ }^{* * *} \mathrm{p}<0.00 \mathrm{I}$ compared with the control group.

treatment with $417 \mathrm{~nm}, 663 \mathrm{~nm}$ and $1047 \mathrm{~nm}$ GO NPs than the control group. The $4651 \mathrm{~nm}$ GO NP-treated cells showed enhanced migration of the mNSCs over a longer distance compared with that in the control group; however, the migration was not as much as in the other GO groups. To determine the underlying mechanism of GO NP effect on the migration of mNSCs, the expression of focal adhesion-related genes Rap1, Vinculin and Paxillin were analyzed at the mRNA level using qPCR. As shown in Figure 6C, we observed significant increases in the expression of Rap1, Vinculin and Paxillin in the GO NPs-treated groups compared with the control group, which explained the improved migration of mNSC.

\section{ERK I/2 Signal Pathway Is Involved in 465I nm GO NP-Induced Neuronal Differentiation of NSCs}

As the $4651 \mathrm{~nm}$ GO NPs-treated mNSCs had the highest tendency for undergoing neuronal differentiation, it was still not clear why it could enhance the differentiation only to a certain degree. To understand the underlying mechanism, a comprehensive transcriptome analysis was performed using mRNA-sequence analysis with 2D principal component analysis (2D PCA). We observed that for both the samples, all the genes could be clearly distinguished for $4651 \mathrm{~nm}$ GO NPtreated group than the control group (each group consisted of samples in replicates) (Figure 7A). The differentially expressed genes were enriched and divided into several apparent signaling pathways using Gene Ontology and Kyoto Encyclopedia of Genes and Genomics (KEGG) analysis, respectively (Figure $7 \mathrm{~B}$ and $\mathrm{C}$ ). Among the differentially expressed genes, we picked out TRPC2, a gene related to axon growth, which was downregulated dramatically in this group. Generally, downregulation of TRPC2 leads to phosphorylation of ERK1/2, ${ }^{33}$ which in turns, initiates neuronal differentiation of NSCs. ${ }^{34-36}$ Therefore, the ERK1/2 signal pathway was chosen for further studies. The effect of 4651 nm GO NPs on the mNSC was examined using Western blotting and q-PCR. As is shown in Figure 7E, TRPC2 
A
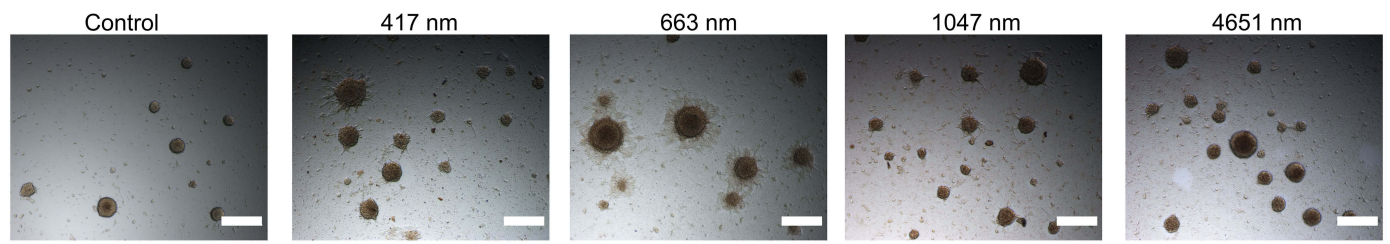

B

Control

$417 \mathrm{~nm}$

$663 \mathrm{~nm}$

1047 nm

$4651 \mathrm{~nm}$
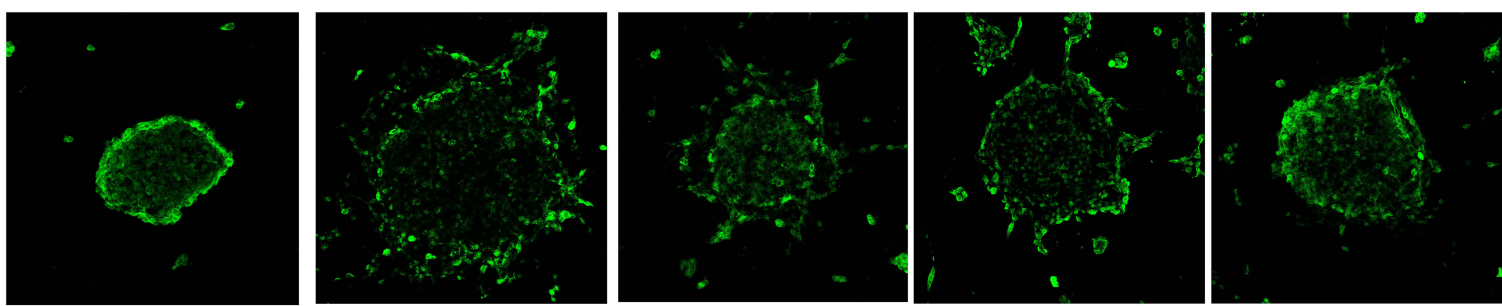

DAPI
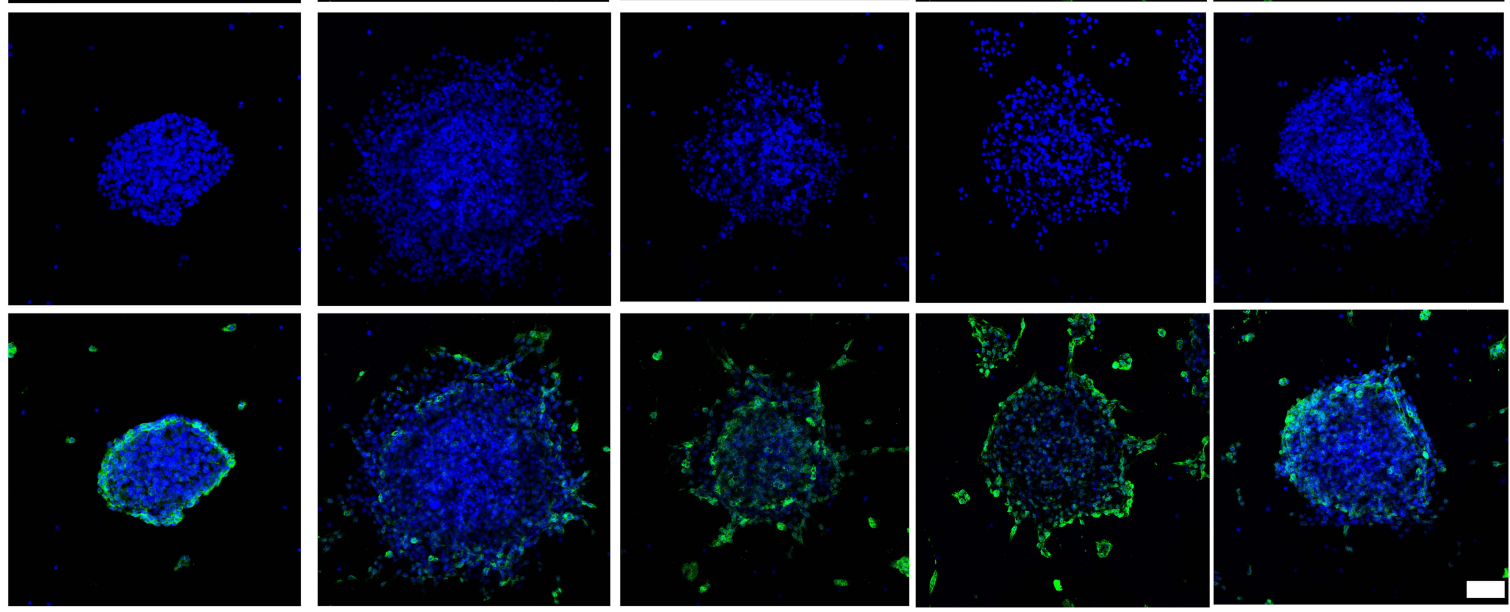

C
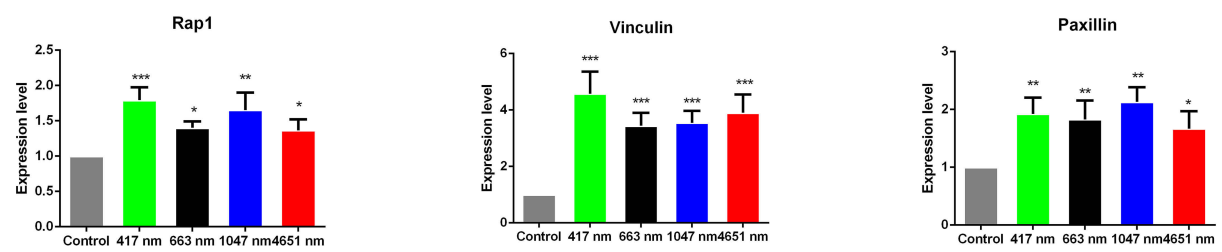

Figure 6 Effects of graphene oxide nanoparticles on the migration of mNSCs. (A) Bright field images of the neurospheres treated with $417 \mathrm{~nm}$, $663 \mathrm{~nm}$, $1047 \mathrm{~nm}$ and $465 \mathrm{I} \mathrm{nm} \mathrm{GO} \mathrm{NPs}(20 \mu \mathrm{g} / \mathrm{mL})$ for $24 \mathrm{hrs}$. Scale bars: $500 \mu \mathrm{m}$. (B) Immunofluorescence images of mNSCs treated with $417 \mathrm{~nm}, 663 \mathrm{~nm}, 1047 \mathrm{~nm}$ and $465 \mathrm{I} \mathrm{nm}$ GO NPs $(20 \mu \mathrm{g} / \mathrm{mL}$ ) for $24 \mathrm{hrs}$. The cells were co-stained with Nestin (green) and nuclei (blue). Scale bars: $50 \mu \mathrm{m}$. (C) Relative mRNA expression levels of the focal adhesion gene Rap I, Vinculin, and Paxillin were shown. GAPDH was used for internal normalization in the quantitative RT-PCR. Data show the means \pm standard error of the mean of three independent experiments. ${ }^{* * *} p<0.001$, ${ }^{*} p<0.01$ and $*_{p}<0.05$ compared with the control group.

expression in the $4651 \mathrm{~nm}$ GO NP-treated cells was dramatically lower than in the control group, which is consistent with the mRNA-sequence analysis results (Figure 7D). Besides, treatment of mNSCs, with the $4651 \mathrm{~nm}$ increasingly enhanced the expression level of pERK1/2, showing that it is likely that the enhancement of NSC differentiation via ERK1/2 signaling pathway is the key underlying mechanism.

\section{Discussion}

In vitro and in vivo studies have shown that hydrophilic GO NPs are less toxic than the hydrophobic ones. ${ }^{37-40}$ The suspended graphene particles tend to agglomerate in the cell culture medium, covering the cell surface as the concentration increases, limiting the nutrient supply and leading to oxidative stress-induced apoptosis. However, as GO is more stable in solution, it can be used for easy absorption of proteins on the cell surface by avoiding direct interaction with the cells, and hence reducing the cytotoxicity. The cytotoxicity of the suspended GO NPs depends mainly on surface chemistry, particle size, shape and concentration. ${ }^{41,42}$ Meanwhile, the rations of carbon-tooxygen of four GO NPs are measured by a FEI Titan G2 80-300, which is a STEM integrated with corrected electron optics, to measure the carbon-to-oxygen ration of GO 

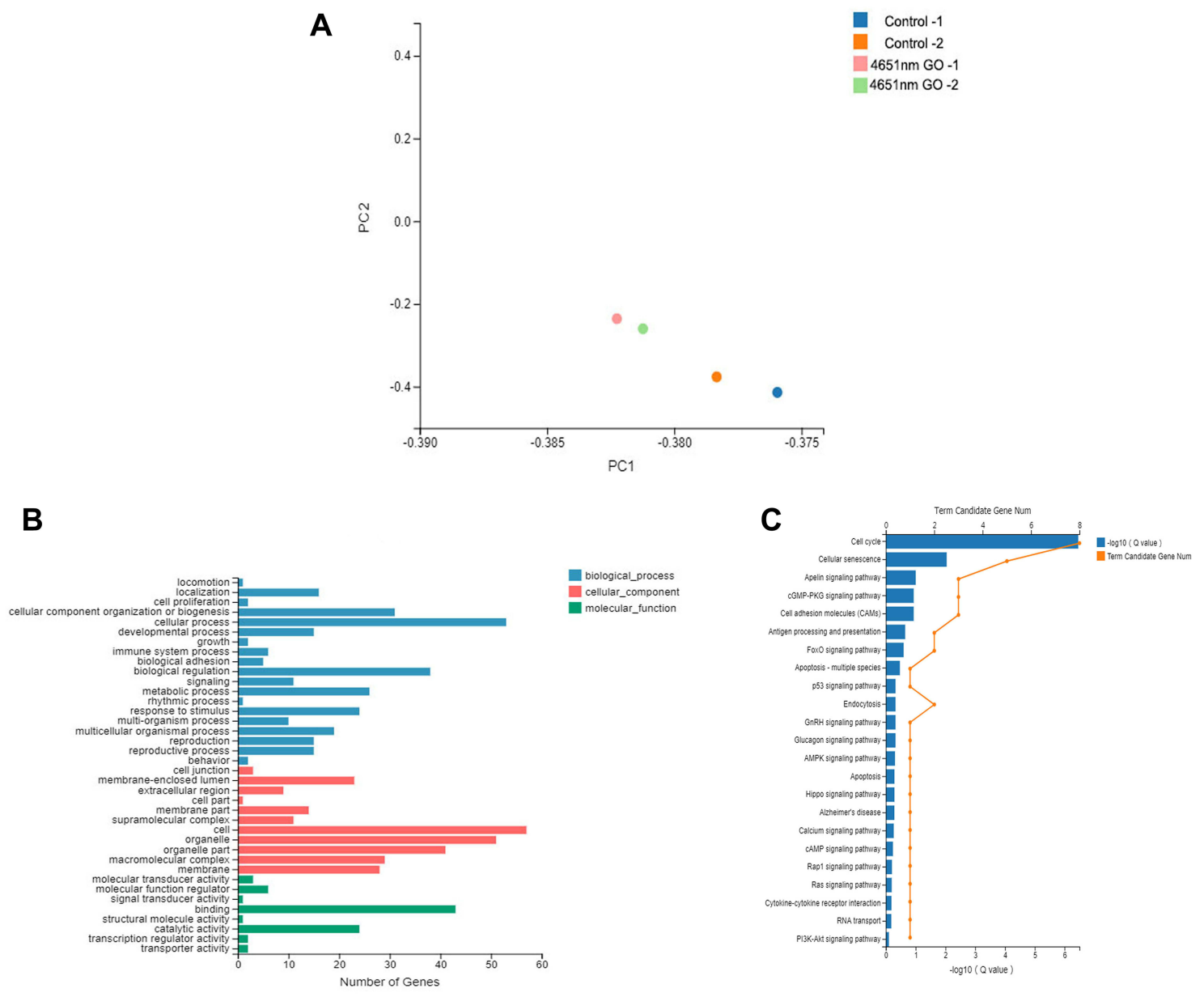

D

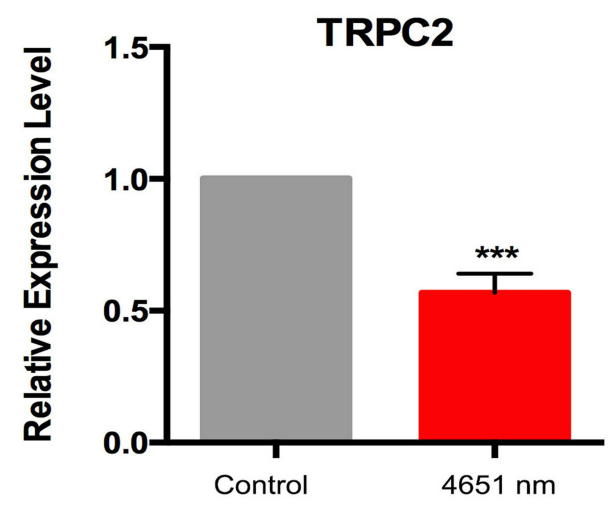

E Control $4651 \mathrm{~nm}$

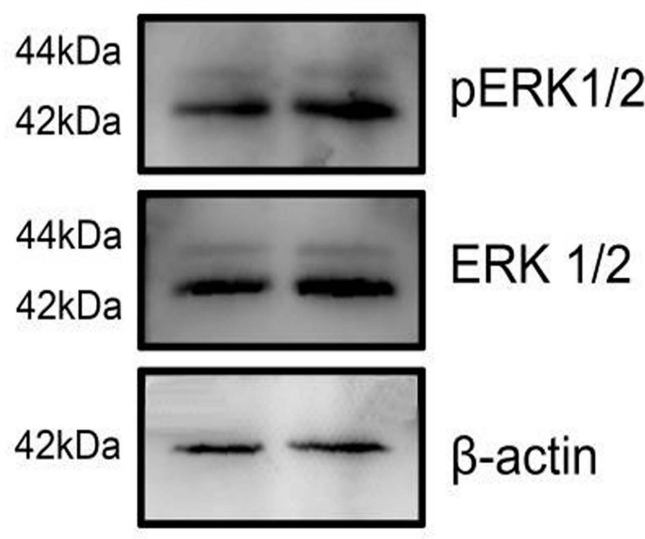

Figure 7 Effects of $465 \mathrm{I} \mathrm{nm}$ graphene oxide nanoparticles on the differentiation mechanism of mNSCs. (A) 2D principal component analysis using the genome-wide expression data for the $465 \mathrm{I} \mathrm{nm} \mathrm{GO} \mathrm{NPs} \mathrm{and} \mathrm{control} \mathrm{group} \mathrm{using} \mathrm{R} \mathrm{Studio.} \mathrm{(B)} \mathrm{KEGG} \mathrm{pathway} \mathrm{analysis} \mathrm{of} \mathrm{the} \mathrm{genes} \mathrm{regulated} \mathrm{in} \mathrm{the} 465 \mathrm{I}$ nm GO NP-treated mNSCs. (C) GO pathway analysis of the regulated genes in the $465 \mathrm{Imm}$ GO NP-treated mNSC. (D) Relative mRNA expression levels of gene TRPC2, GAPDH was used for internal normalization in the quantitative RT-PCR. Data show the means \pm standard error of the mean of three independent experiments. $* * * p<0.00 \mathrm{I}$ compared with the control group. (E) Western blotting results.

NPs. The principle edges of carbon and oxygen are $284 \mathrm{eV}$ and $532 \mathrm{eV}$, respectively, and the rations of carbon-tooxygen of four GO NPs are calculated. ${ }^{43}$ As is shown in Figure S3, the rations of the carbon-to-oxygen of four sizes are 11:1 $(417 \mathrm{~nm}), 11.2: 1(663 \mathrm{~nm}), 11.7: 1(1047$ $\mathrm{nm})$ and 12.5:1 (4651 nm). With the hydrophilicity of GO NPs decreasing, the carbon-to-oxygen ration increases, which probably affects its solubility and toxicity. ${ }^{44}$ In our 
study, GO NPs of approximately $5 \mu \mathrm{m}$ size exhibited higher cytotoxicity than other GO NPs at concentrations of $100 \mu \mathrm{g} / \mathrm{mL}$, possibly because of greater coverage of the cell surface leading to nutrient deficiency and more oxidative stress-induced apoptosis.

Several studies have demonstrated that the fate of theNSCs is determined by both the internal genes and exogenous signals. Internal regulation refers to the regulation via transcription factors belonging to the Notch signaling pathway, bHLH transcription factor family and Wnt signal pathway. ${ }^{45,46}$ They are activated in a specific manner leading to activation or inhibition of the expression of downstream genes, and ultimately influencing the proliferation and differentiation of NSCs. Exogenous signal regulation refers to the regulation of several aspects of the microenvironment in which NSCs are located, including cytokines, ${ }^{9,47}$ extracellular matrix (ECM) ${ }^{48}$ and neighboring cells. ${ }^{49,50}$

The composition and concentration of cytokines-like growth factors determine the fate of stem cells by transferring exogenous signals into cells through the corresponding membrane receptor. In this study, surprisingly, we found that GO NPs are capable of replacing EGF and bFGF in maintaining the self-renewal of mNSCs in vitro to some extent. GO NPs possess special surface topography and mechanical properties such as hardness, elasticity and porosity, which provide similar growth environment for stem cells like NSCs. ${ }^{51-54}$ In addition to the structural topography and mechanical properties, the interaction between the stem cells and the biomaterials have also accounted for cellular behavior. ${ }^{55}$ Stress from ECM can possibly activate or suppress certain genes specific to proliferation and differentiation of NSCs, leading to promotion of self-renewal. ${ }^{49,56}$ Notably, there is higher possibility of smaller suspended GO NPs interacting with mNSCs than larger ones, which may explain the better ability of $417 \mathrm{~nm}$ and $663 \mathrm{~nm}$ GO NPs in maintaining selfrenewal of mNSCs. However, the exact mechanism of GO NPs in maintaining the self-renewal of mNSCs in the absence of EGF and bFGF is still unclear and needs further investigation.

The extracellular matrix consists of a variety of glycoproteins and mucins that influence the and differentiation of NSCs by regulating their adhesion and migration. ${ }^{57}$ Due to the unique characteristics of NPs such as specific nanoscale morphology, roughness and elasticity, GO NPs can mimic the extracellular matrix microenvironment, enabling the adsorption of biomolecules and the formation of adhesive spots. ${ }^{58,59}$ Under conditions that induce differentiation, the attachment of the cells was reinforced and the relative focal adhesion signaling pathway was activated after treatment with GO NPs, resulting in increased expression of Rap1, Vinculin and Paxillin. Moreover, mNSCs attached to the GO matrix after treatment with PLO in the differentiation medium, where the $4651 \mathrm{~nm}$ GO NPs had larger area to form adhesion spots. This could be one of the reasons for the enhanced performance of the $4651 \mathrm{~nm}$ GO NPs in accelerating the differentiation and improving migration of the mNSCs.

It is also worth noting that the cellular response of mNSCs mediated by GO NPs exhibited significant dependency on the particle size. ${ }^{60,61}$ Previous research has shown that after addition into the culture medium, NPs rapidly absorb small molecules selectively onto their surface and a layer of molecules, also known as corona, is generated that can enable interaction with the cells. The chemical composition and thickness of the corona layer, which is determined by the size of NPs, influences the cellular functions, including cellular uptake, cytotoxicity and gene expression. ${ }^{62,63}$ However, the exact mechanism of the size-dependent effects of GO NPs on the cytotoxicity, self-renewal, differentiation and migration of mNSCs is still unclear, and requires further relevant research.

TRPC2, TRPC1 and TRPC3 belongs to the family of transient receptor potential canonical (TRPC) genes. TRPCs are potential $\mathrm{Ca} 2+$ cation channels and influence the cellular functions through the entry of $\mathrm{Ca}^{2+}$, which triggers changes in the action potentials in the neurons. TRPC2 is unique among TRPCs ${ }^{33}$ and its physiological roles have been studied in rat thyroid FRTL-5 cells. In these cells, it was seen that knockdown of TRPC2 leads to the increase in cAMP levels, leading to a rise in Rasrelated protein 1-MAPK kinase 1(MAPK/ERK Kinase 1) along with stimulation of ERK1/2 phosphorylation. ${ }^{64}$ From the signal transduction point of view, ERK1/2 phosphorylation induces expression of specific proteins that regulate cellular proliferation, differentiation and apoptosis. Our Western blotting analysis shows that the expression of pERK1/2 was higher in the $4651 \mathrm{~nm}$ GO NPs group than in the control group. This indicates that the addition of GO NPs stimulates ERK1/2 phosphorylation, which plays an important role in neuronal growth. With regard to gliogenesis, TRPC3-induced $\mathrm{Ca}^{2+}$ signals might be related to the growth of astrocytes, which is attenuated in the presence of TRPC1. As the primer sequences and lengths for TRPC1 and TRPC2 are similar (171 bp and 


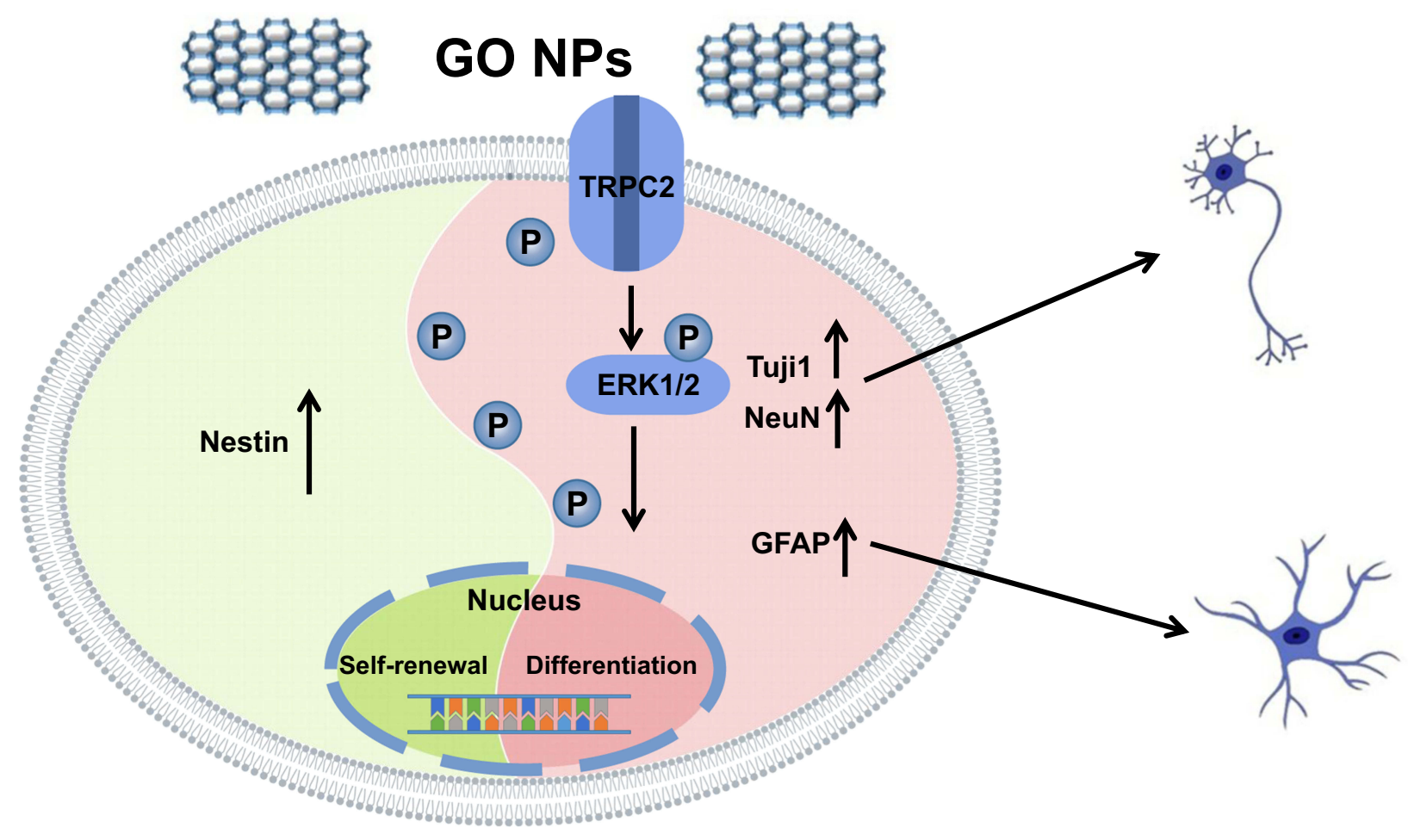

Figure 8 Schematic representation summarizing the role of graphene oxide nanoparticles on the self-renewal and differentiation of mNSCs.

$173 \mathrm{bp}$, respectively), we assumed that the downregulation of TPRC2 may lead to the growth of astrocytes. ${ }^{65}$ However, further studies need to be conducted to show the other signal pathways that are involved in this mechanism.

Taken together (Figure 8), our study shows that GO NPs play an important role in the self-renewal of NSCs, as shown by the strong expression of Nestin. However, TRPC 2 gene as well as TRPC2 protein, which is a $\mathrm{Ca} 2+$ ion channel, was downregulated. The ERK signaling pathway was activated and the levels of certain markers, such as Tuj1, NeuN and GFAP were also upregulated. Overall, these results show that GO NPs may act as potential candidates for nanomedicines for the regulation of cellular fate.

\section{Conclusion}

Overall, in this study, we compared the effects of GO NPs of four different sizes on the biocompatibility, self-renewal and differentiation of mNSCs. We observed that GO NPs of all sizes presented less cytotoxicity at concentrations $\leq 20 \mu \mathrm{g} / \mathrm{mL}$. Larger GO NPs (approximately $1 \mu \mathrm{m}$ and $5 \mu \mathrm{m}$ in size) showed more obvious cytotoxicity than small GO NPs (approximately $400 \mathrm{~nm}$ and $700 \mathrm{~nm}$ in size) at high concentrations. Through analysis of the expression of self-renewal and differentiationrelated genes, we found that the $417 \mathrm{~nm}$ and $663 \mathrm{~nm}$ GO NPs exhibited more outstanding ability to maintain the self-renewal of mNSCs in the absence of EGF and bFGF, while $4651 \mathrm{~nm}$ GO NPs were more efficient in accelerating the differentiation of mNSCs under differentiation conditions. In addition, 417 $\mathrm{nm}$ GO NPs can promote the migration of mNSCs by upregulating the expression of Vinculin significantly. Finally yet importantly, $4651 \mathrm{~nm}$ GO NPS clearly enhanced neuronal differentiation in the mNSCs through phosphorylation of ERK1/2 via downregulation of TRPC2.

\section{Acknowledgments}

This work was financially supported by the National key research and development program (Grant No. 2016Y FA0100800), the National Natural Science Foundation of China (Grant No.81922039, 81873994, 31727801, 8167 1105), and the Fundamental Research Funds for the Central Universities.

\section{Disclosure}

No potential conflicts of interest were disclosed by the authors.

\section{References}

1. Gage FH. Mammalian neural stem cells. Science. 2000;287 (5457):1433-1438. doi:10.1126/science.287.5457.1433 
2. Temple S. The development of neural stem cells. Nature. 2001;414 (6859):112-117. doi:10.1038/35102174

3. Johansson CB, Momma S, Clarke DL, Risling M, Lendahl U, Frisen J. Identification of a neural stem cell in the adult mammalian central nervous system. Cell. 1999;96(1):25-34. doi:10.1016/S00928674(00)80956-3

4. Reynolds BA, Weiss S. Generation of neurons and astrocytes from isolated cells of the adult mammalian central-nervous-system. Science. 1992;255(5052):1707-1710. doi:10.1126/science.1553558

5. McGrath EL, Gao JL, Wu P. Proliferation and differentiation of human fetal brain neural stem cells in vitro. $J$ Neurorestoratol. 2018;6:19-27. doi:10.2147/JN.S148794

6. Cummings BJ, Uchida N, Tamaki SJ, et al. Human neural stem cells differentiate and promote locomotor recovery in spinal cord-injured mice. Proc Natl Acad Sci U S A. 2005;102(39):14069-14074. doi:10.1073/pnas.0507063102

7. Lindvall O, Kokaia Z, Martinez-Serrano A. Stem cell therapy for human neurodegenerative disorders - how to make it work. Nat Med. 2004;10(7):S42-S50. doi:10.1038/nm1064

8. Martino G, Pluchino S. The therapeutic potential of neural stem cells. Nat Rev Neurosci. 2006;7(5):395-406. doi:10.1038/nrn1908

9. Ciccolini F, Svendsen CN. Fibroblast growth factor 2 (FGF-2) promotes acquisition of epidermal growth factor (EGF) responsiveness in mouse striatal precursor cells: identification of neural precursors responding to both EGF and FGF-2. J Neurosci. 1998;18 (19):7869-7880. doi:10.1523/JNEUROSCI.18-19-07869.1998

10. Xia YN. Nanomaterials at work in biomedical research. Nat Mater. 2008;7(10):758-760. doi:10.1038/nmat2277

11. Ferreira L. Nanoparticles as tools to study and control stem cells. J Cell Biochem. 2009;108(4):746-752. doi:10.1002/(ISSN)10974644

12. Ferreira L, Karp JM, Nobre L, Langer R. New opportunities: the use of nanotechnologies to manipulate and track stem cells. Cell Stem Cell. 2008;3(2):136-146. doi:10.1016/j.stem.2008.07.020

13. Ilie I, Ilie R, Mocan T, Bartos D, Mocan L. Influence of nanomaterials on stem cell differentiation: designing an appropriate nanobiointerface. Int $J$ Nanomedicine. 2012;7:2211-2225. doi:10. 2147/IJN.S29975

14. Stankovich S, Dikin DA, Dommett GHB, et al. Graphene-based composite materials. Nature. 2006;442(7100):282-286. doi:10.1038/ nature 04969

15. Zhu Y, Murali S, Cai W, et al. Graphene and graphene oxide: synthesis, properties, and applications (vol 22, pg 3906, 2010). Adv Mater. 2010;22(46):5226. doi:10.1002/adma.201090156

16. Dreyer DR, Park S, Bielawski CW, Ruoff RS. The chemistry of graphene oxide. Chem Soc Rev. 2010;39(1):228-240. doi:10.1039/ B917103G

17. Wang Y, Li ZH, Wang J, Li JH, Lin YH. Graphene and graphene oxide: biofunctionalization and applications in biotechnology. Trends Biotechnol. 2011;29(5):205-212. doi:10.1016/j.tibtech.2011.01.008

18. Wu SY, An SSA, Hulme J. Current applications of graphene oxide in nanomedicine. Int J Nanomedicine. 2015;10:9-24. doi:10.2147/IJN. S 88285

19. Ng AMH, Kenry C, Lim CT, Low HY, Loh KP. Highly sensitive reduced graphene oxide microelectrode array sensor. Biosens Bioelectron. 2015;65:265-273. doi:10.1016/j.bios.2014.10.048

20. Wang Y, Li ZH, Hu DH, Lin CT, Li JH, Lin YH. Aptamer/graphene oxide nanocomplex for in situ molecular probing in living cells. $J \mathrm{Am}$ Chem Soc. 2010;132(27):9274-9276. doi:10.1021/ja103169v

21. Sun XM, Liu Z, Welsher K, et al. Nano-graphene oxide for cellular imaging and drug delivery. Nano Res. 2008;1(3):203-212. doi:10.1007/s12274-008-8021-8

22. Liu Z, Robinson JT, Sun XM, Dai HJ. PEGylated nanographene oxide for delivery of water-insoluble cancer drugs. $\mathrm{J} \mathrm{Am} \mathrm{Chem} \mathrm{Soc.}$ 2008;130(33):10876-+. doi:10.1021/ja803688x
23. Zhang LM, Xia JG, Zhao QH, Liu LW, Zhang ZJ. Functional graphene oxide as a nanocarrier for controlled loading and targeted delivery of mixed anticancer drugs. Small. 2010;6(4):537-544. doi:10.1002/smll.v6:4

24. Goenka S, Sant V, Sant S. Graphene-based nanomaterials for drug delivery and tissue engineering. $J$ Control Release. 2014;173:75-88. doi:10.1016/j.jconrel.2013.10.017

25. Chen BA, Liu M, Zhang LM, Huang J, Yao JL, Zhang ZJ. Polyethylenimine-functionalized graphene oxide as an efficient gene delivery vector. J Mater Chem. 2011;21(21):7736-7741. doi:10.1039/ c1jm10341e

26. Lee WC, Lim C, Shi H, et al. Origin of enhanced stem cell growth and differentiation on graphene and graphene oxide. ACS Nano. 2011;5(9):7334-7341. doi:10.1021/nn202190c

27. Yang DH, Li T, Xu MH, et al. Graphene oxide promotes the differentiation of mouse embryonic stem cells to dopamine neurons. Nanomedicine. 2014;9(16):2445-2455. doi:10.2217/nnm.13.197

28. Weaver CL, Cui XT. Directed neural stem cell differentiation with a functionalized graphene oxide nanocomposite. Adv Healthc Mater. 2015;4(9):1408-1416. doi:10.1002/adhm.201500056

29. Ahlenius H, Kokaia Z. Isolation and generation of neurosphere cultures from embryonic and adult mouse brain. Methods Mol Biol. 2010;633:241-252.

30. Jing G, Wang Z, Zhuang $X$, et al. Suspended graphene oxide nanosheets maintain the self-renewal of mouse embryonic stem cells via down-regulating the expression of vinculin. Biomaterials. 2018;171:1-11. doi:10.1016/j.biomaterials.2018.04.017

31. Ramaswamy S, Goings GE, Soderstrom KE, Szele FG, Kozlowski DA. Cellular proliferation and migration following a controlled cortical impact in the mouse. Brain Res. 2005;1053(1-2):38-53. doi:10.1016/j.brainres.2005.06.042

32. Ourednik V, Ourednik J, Xu YF, et al. Cross-talk between stem cells and the dysfunctional brain is facilitated by manipulating the niche: evidence from an adhesion molecule. Stem Cells. 2009;27 (11):2846-2856. doi:10.1002/stem.v27:11

33. Yildirim E, Birnbaumer L. TRPC2: molecular biology and functional importance. Handb Exp Pharmacol. 2007;179:53-75.

34. Torii S, Nakayama K, Yamamoto T, Nishida E. Regulatory mechanisms and function of ERK MAP kinases. J Biochem. 2004;136 (5):557-561. doi:10.1093/jb/mvh159

35. Shinjyo N, Stahlberg A, Dragunow M, Pekny M, Pekna M. Complement-derived anaphylatoxin c3a regulates in vitro differentiation and migration of neural progenitor cells. Stem Cells. 2009;27 (11):2824-2832. doi:10.1002/stem.225

36. Kim SY, Han YM, Oh M, et al. DUSP4 regulates neuronal differentiation and calcium homeostasis by modulating ERK1/2 phosphorylation. Stem Cells Dev. 2015;24(6):686-700. doi:10.1089/ scd.2014.0434

37. Zhang XY, Yin JL, Peng C, et al. Distribution and biocompatibility studies of graphene oxide in mice after intravenous administration. Carbon. 2011;49(3):986-995. doi:10.1016/j.carbon.2010.11.005

38. Yang K, Gong H, Shi XZ, Wan JM, Zhang YJ, Liu Z. In vivo biodistribution and toxicology of functionalized nano-graphene oxide in mice after oral and intraperitoneal administration. Biomaterials. 2013;34(11):2787-2795. doi:10.1016/j.biomaterials. 2013.01.001

39. Seabra AB, Paula AJ, de Lima R, Alves OL, Duran N. Nanotoxicity of graphene and graphene oxide. Chem Res Toxicol. 2014;27 (2):159-168. doi:10.1021/tx400385x

40. Lalwani G, D'Agati M, Khan AM, Sitharaman B. Toxicology of graphene-based nanomaterials. Adv Drug Deliv Rev. 2016;105:109-144. doi:10.1016/j.addr.2016.04.028

41. Mendes RG, Koch B, Bachmatiuk A, et al. A size dependent evaluation of the cytotoxicity and uptake of nanographene oxide. $J$ Mater Chem B. 2015;3(12):2522-2529. doi:10.1039/C5TB00180C 
42. Wang INE, Robinson JT, Do G, et al. Graphite oxide nanoparticles with diameter greater than $20 \mathrm{~nm}$ are biocompatible with mouse embryonic stem cells and can be used in a tissue engineering system. Small. 2014;10(8):1479-1484. doi:10.1002/smll.201303133

43. Liu AR, Zhang WX. Fine structural features of nanoscale zero-valent iron characterized by spherical aberration corrected scanning transmission electron microscopy (Cs-STEM). Analyst. 2014;139 (18):4512-4518. doi:10.1039/C4AN00679H

44. Zhao J, Tang M, Cao J, et al. Structurally tunable reduced graphene oxide substrate maintains mouse embryonic stem cell pluripotency. Adv Sci (Weinh). 2019;6(12):1802136. doi:10.1002/advs.201802136

45. Piccin D, Morshead CM. Wnt signaling regulates symmetry of division of neural stem cells in the adult brain and in response to injury. Stem Cells. 2011;29(3):528-538. doi:10.1002/stem.v29.3

46. Aguirre A, Rubio ME, Gallo V. Notch and EGFR pathway interaction regulates neural stem cell number and self-renewal. Nature. 2010;467 (7313):323-U101. doi:10.1038/nature09347

47. Cattaneo E, McKay R. Proliferation and differentiation of neuronal stem-cells regulated by nerve growth-factor. Nature. 1990;347 (6295):762-765. doi:10.1038/347762a0

48. Brizzi MF, Tarone G, Defilippi P. Extracellular matrix, integrins, and growth factors as tailors of the stem cell niche. Curr Opin Cell Biol. 2012;24(5):645-651. doi:10.1016/j.ceb.2012.07.001

49. Discher DE, Mooney DJ, Zandstra PW. Growth factors, matrices, and forces combine and control stem cells. Science. 2009;324 (5935):1673-1677. doi:10.1126/science.1171643

50. Spradling A, Drummond-Barbosa D, Kai T. Stem cells find their niche. Nature. 2001;414(6859):98-104. doi:10.1038/35102160

51. Dalby MJ, Gadegaard N, Oreffo ROC. Harnessing nanotopography and integrin-matrix interactions to influence stem cell fate. Nat Mater. 2014;13(6):558-569. doi:10.1038/nmat3980

52. Chen WQ, Villa-Diaz LG, Sun YB, et al. Nanotopography influences adhesion, spreading, and self-renewal of human embryonic stem cells. ACS Nano. 2012;6(5):4094-4103. doi:10.1021/nn3004923

53. Even-Ram S, Artym V, Yamada KM. Matrix control of stem cell fate. Cell. 2006;126(4):645-647. doi:10.1016/j.cell.2006.08.008

54. Engler AJ, Sen S, Sweeney HL, Discher DE. Matrix elasticity directs stem cell lineage specification. Cell. 2006;126(4):677-689. doi:10. 1016/j.cell.2006.06.044
55. Nel AE, Madler L, Velegol D, et al. Understanding biophysicochemical interactions at the nano-bio interface. Nat Mater. 2009;8 (7):543-557. doi:10.1038/nmat2442

56. Wong JY, Leach JB, Brown XQ. Balance of chemistry, topography, and mechanics at the cell-biomaterial interface: issues and challenges for assessing the role of substrate mechanics on cell response. Surf Sci. 2004;570(1-2):119-133. doi:10.1016/j.susc.2004.06.186

57. Solanki A, Shah S, Memoli KA, Park SY, Hong S, Lee KB. Controlling differentiation of neural stem cells using extracellular matrix protein patterns. Small. 2010;6(22):2509-2513. doi:10.1002/ smll.201001341

58. Fusco S, Panzetta V, Embrione V, Netti PA. Crosstalk between focal adhesions and material mechanical properties governs cell mechanics and functions. Acta Biomater. 2015;23:63-71. doi:10.1016/j. actbio.2015.05.008

59. Gautrot JE, Malmstrom J, Sundh M, Margadant C, Sonnenberg A, Sutherland DS. The nanoscale geometrical maturation of focal adhesions controls stem cell differentiation and mechanotransduction. Nano Lett. 2014;14(7):3945-3952. doi:10.1021/n1501248y

60. Wu YJ, Zhu RR, Ge X, et al. Size-dependent effects of layered double hydroxide nanoparticles on cellular functions of mouse embryonic stem cells. Nanomedicine. 2015;10(23):3469-3482. doi: $10.2217 / \mathrm{nnm} .15 .158$

61. Shang L, Nienhaus K, Nienhaus GU. Engineered nanoparticles interacting with cells: size matters. J Nanobiotechnology. 2014;12:5.

62. Jiang W, Kim BYS, Rutka JT, Chan WCW. Nanoparticle-mediated cellular response is size-dependent. Nat Nanotechnol. 2008;3 (3):145-150. doi:10.1038/nnano.2008.30

63. Akhavan O, Ghaderi E, Akhavan A. Size-dependent genotoxicity of graphene nanoplatelets in human stem cells. Biomaterials. 2012;33 (32):8017-8025. doi:10.1016/j.biomaterials.2012.07.040

64. Lof C, Sukumaran P, Viitanen T, et al. Communication between the calcium and cAMP pathways regulate the expression of the TSH receptor: TRPC2 in the center of action. Mol Endocrinol. 2012;26 (12):2046-2057. doi:10.1210/me.2012-1171

65. Belkacemi T, Niermann A, Hofmann L, et al. TRPC1- and TRPC3-dependent $\mathrm{Ca}(2+)$ signaling in mouse cortical astrocytes affects injury-evoked astrogliosis in vivo. Glia. 2017;65 (9):1535-1549. doi:10.1002/glia.23180
International Journal of Nanomedicine

\section{Publish your work in this journal}

The International Journal of Nanomedicine is an international, peerreviewed journal focusing on the application of nanotechnology in diagnostics, therapeutics, and drug delivery systems throughout the biomedical field. This journal is indexed on PubMed Central, MedLine, CAS, SciSearch ${ }^{\circledR}$, Current Contents ${ }^{\mathbb{R}} /$ Clinical Medicine,
Journal Citation Reports/Science Edition, EMBase, Scopus and the Elsevier Bibliographic databases. The manuscript management system is completely online and includes a very quick and fair peer-review system, which is all easy to use. Visit http://www.dovepress.com/ testimonials.php to read real quotes from published authors. 